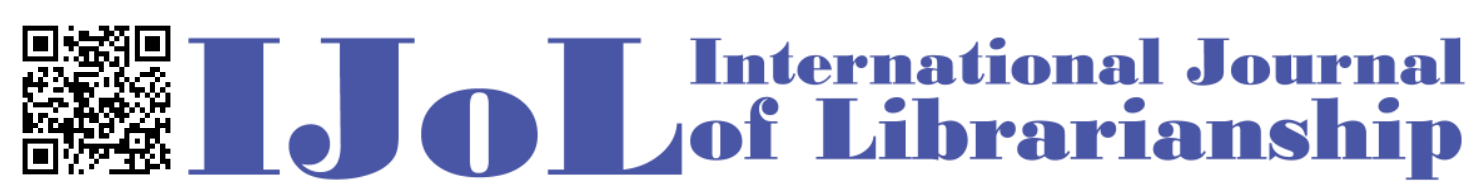

ISSN: 2474-3542 Journal homepage: http://journal.calaijol.org

\title{
Partnering with Special Collections in Promoting Digital Humanities: Papers of Charles Daniel Tenney (丁家立档案 ) at Dartmouth College
}

\author{
Nien Lin Xie
}

\begin{abstract}
:
This paper discusses a project relating to the papers of Charles Tenney at Dartmouth College in order to examine the value of partnering with special collections while promoting digital humanities. It treats the discovery, digitization, publication and utilization of rare and unique primary resources in assisting classroom teaching and research. This project provides a case study that illustrates how, by creating collaborative projects with faculty and colleagues, librarians can create knowledge, enrich scholarship, and better serve academic communities as research partners instead of being mere content providers.
\end{abstract}

To cite this article:

Xie, N.L. (2019). Partnering with Special Collections in Promoting Digital Humanities: Papers of Charles Daniel Tenney (丁家立档案) at Dartmouth College. International Journal of Librarianship, 4(1), 103-107.

To submit your article to this journal:

Go to http://ojs.calaijol.org/index.php/ijol/about/submissions 


\title{
Partnering with Special Collections in Promoting Digital Humanities: \\ Papers of Charles Daniel Tenney (丁家立档案) at Dartmouth College $^{1}$
}

\author{
Nien Lin Xie \\ Dartmouth College, Hanover, New Hampshire, USA
}

\begin{abstract}
This paper discusses a project relating to the papers of Charles Tenney at Dartmouth College in order to examine the value of partnering with special collections while promoting digital humanities. It treats the discovery, digitization, publication and utilization of rare and unique primary resources in assisting classroom teaching and research. This project provides a case study that illustrates how, by creating collaborative projects with faculty and colleagues, librarians can create knowledge, enrich scholarship, and better serve academic communities as research partners instead of being mere content providers.
\end{abstract}

Keywords: Charles Daniel Tenney; Education in China; Digital humanities; Special collections

\section{INTRODUCTION}

In today's academic library world, special collections are playing a larger role than ever before. While both print and electronic resources can be purchased, subscribed to and often shared among libraries, unique and rare materials can only be found in special collections at individual institutions. Until recently, the only means to access materials in such special collections was to travel to the locations and use them on site. Implementation of open access policies and development of digitization technology have paved the way for the discovery and utilization of a great number of these resources in recent years. The project of Charles Tenney's papers that I conducted at Dartmouth College Library in 2012 is a case in point.

Charles Tenney was an American educator and diplomat. He played a pivotal role in pioneering China's modern educational system and was a well-known person in the history of USChina relations during the $19^{\text {th }}$ century. In this paper, I introduce Tenney's papers' project from

\footnotetext{
${ }^{1}$ Early version presented at the 9th Shanghai International Library Forum and published in the conference proceedings as follows: Nien Lin Xie (2018). Partnering with Special Collections in Promoting Digital Humanities: Papers of Charles Daniel Tenney (丁家立档案) at Dartmouth. In Proceedings of Shanghai International Library Forum (SILF), October 18-19, 2018, Shanghai, China.
} 
the initial discovery to its digitization and transcription, online publication, and to a further collaborative project of translation and scholarship that finally led to the making of the book Ding Jiali dang an = The Papers of Charles Daniel Tenney (丁家立档案). I also explain how we integrated the resource with classroom teaching and standardized it as a paper assignment for a history class at Dartmouth, "History of Modern China since 1800" taught by Professor Pamela Crossley in the History Department. This instance demonstrates that by exploring hidden treasures at special collections and making them available to classrooms and the wider world, we can increase the value and extend the impact of rare resources, "using the past to serve the present" as a Chinese saying goes. We can also create new knowledge and scholarship by adding new contents through publication. I would further argue that librarians can better serve our academic institutions by being research partners rather than merely being content providers.

\section{CHARLES DANIEL TENNEY AND HIS PAPERS}

Nestled in the picturesque New England town of Hanover where Dartmouth College is situated, Rauner Specials Collections Library has been a treasure house of extraordinary rare books, manuscripts and archival materials. It houses the first of edition of The Book of Mormon, William Shakespeare's First Folio, the original version of Dickens' David Copperfield, The Robert Frost Papers, one of the largest and most important collections of Robert Frost works and Collection of George Washington's Papers, just to name a few. One largely unknown item in the collection is the first edition of Quotations from Chairman Mao Tse-tung published in 1964 in two volumes, one for the cadres and one for the rank and files. The head of Rauner Library, Jay Satterfield, once said that he bought the little red book for Dartmouth students to gain a glimpse to the most sold book in the world. To best assist campus teachings, Rauner Library is equipped with classrooms, scanners and cameras. Professors and students have direct access to all the materials which they can touch, flip through and examine with bare hands. I have personally taught classes there using books and artifacts in the collection.

Among Rauner Library's treasured items is, one particularly interesting folder, the Papers of Charles Daniel Tenney. Graduated from Dartmouth in 1878, Tenney went to China as a missionary in 1882, and moved to Tianjin after three years to focus on elite education. In 1886, Tenney organized the Anglo-Chinese school, and shortly after, his insight in modern education caught the attention of Viceroy Li Hongzhang, the most powerful man in China at the time. Li invited him to be a tutor for his own children at home.

In 1895, Tenney was appointed by Sheng Xuanhuai, Li Hongzhang's chief economic deputy and the Minister of Transportation of the Qing Dynasty, to be the President of Beiyang University, the first comprehensive Western style university in China and the predecessor of Tianjin University. He held that position for eleven years. Education at Beiyang University was interrupted as a result of the Boxer Rebellion of 1900, and Tianjin was occupied by foreign troops and a provisional government for the district was set up. From 1900 to 1902, Tenney served as Chinese Secretary of the Tianjin Provisional Government.

In 1902 Tenney made a trip to Berlin to take up with the German Government the question of compensation for the incorporation in the German Concession at Tientsin (Tianjin) of the original site of Peiyang (Beiyang) University. He was successful in obtaining an indemnity for the 
seized property, thereby enabling the University to erect new buildings at Hsiku in the north suburbs. ("Dartmouth College Library Guide", n.d.)

In 1906 Dr. Tenney retired as President of Peiyang (Beiyang) University and was appointed Director of Chinese Government students in the United States, in which capacity he remained until 1908, making his headquarters at Cambridge, Massachusetts. He brought with him to the United States for further study about thirty members of the Senior Class of Peiyang (Beiyang) University. On March 2, 1907 Tenney returned to Dartmouth as the director of Chinese government students. He had trained over fifty percent of the more than one hundred Chinese students who had enrolled in graduate programs at Ivy League institutions and MIT between 1901 and 1907. Many notable alumni from his university eventually took leading positions in various fields in China and played important roles in modern Chinese history. ("Dartmouth College Library Guide", n.d.)

Tenney's papers contain seven essays and a speech, consisting of partially typed texts and a partially handwritten manuscript. The essays are believed to be written between 1907 to 1925 , after his career as the president of Beiyang University. Biographical in nature, they touch on China's educational reform, cultural values, religious history, the Republic of China, the modernization of Chinese language, and Viceroy Li Hongzhang. The folder also includes Tenney's English translation of two Kaifeng temple stones, as well as a chapter on Kaifeng Synagogue and Kaifeng Jews community. It is worth mentioning that Kaifeng Synagogue in the City of Kaifeng in Henan Province was the home of the only Jewish synagogue in China before it was burned down in 1860s. Tenney's vivid travel account to the site and his detailed description of the two stele monuments are valuable first-hand eyewitness to the history of Jewish community in Kaifeng. All in all, the papers were so eloquently written that they do not only acutely reflect Tenney's keen interests in China affairs, but also reveal his passion and longing to China's success.

\section{THE DIGITIZATION PROJECT}

The papers first came to Professor Crossley's attention when a visiting researcher from Princeton University came to Dartmouth to use them. Later, she introduced them to Niu Guanjie, a history professor from Renmin University of China and a visiting scholar at Dartmouth in 2007, whose research interest was in US-China relations in late $19^{\text {th }}$ century. In 2010 , the year after I became the East Asian Librarian at Dartmouth, I began to think how wonderful it would be to have the papers digitally available as online primary sources, accessible to classrooms on campus and all. My recognition was partly in response to the library call to propose digitization projects at that moment and partly a result of conversations with Professor Crossley. By then, Tenney's papers had been lying at Rauner Library for over 70 years.

In the spring of 2012, I proposed to the library administration to have the papers digitized. The immediate driving force at the time was to have them published on the college website for Crossley's history class in the fall term. The proposal was accepted almost instantly, and a project team was formed. Some torn pages were repaired by the preservation department; the papers were scanned by the digital production team and converted to machine-readable text using optical character recognition. TEI markup was applied in the cataloging department, encoding the texts and making them keyword-searchable. TEI stands for Text Encoding Initiative, which develops and maintains a standard for the representation of texts in digital form (https://tei-c.org). In October 
2012, the papers came alive as an open access online resource, just in time for the class. Since then, they have become a standard class paper assignment. Professor Crossley requires her students to use the papers as the basis of a research exercise, exploring topics as various as the family attitudes of Li Hongzhang, the origins of the modern transliteration system for Chinese, and the Jewish monuments in Kaifeng. In evaluating the project, Crossley expressed the importance of the online access of the original materials for students in historical research and in understanding the period of China from 1882 to 1920, a critical historical moment in Chinese history. (Crossley, 2013)

Inspired by the compelling richness of the papers, my colleague at Binghamton University, Julie Wang and I explored the possibility of further scholarship with Tenney's project. We asked ourselves: Wouldn't a translation into Chinese be useful to scholars of history at Tianjin University? To those who can only read Chinese? Wouldn't further research be meaningful to this scarcely studied yet influential historical figure in contemporary Chinese education?

In 2013, at the annual meeting of the Society of Chinese studies librarians, Julie and I presented Tenney's project. The head of Guangxi Normal University Press, He Linxia, approached us to express his interest in publishing a translated volume accompanied by scans of the original documents. Ding Ye, our colleague from Georgetown University, agreed to join us in the translation. We invited Professor Crossley to write an essay "Charles Tenney's Remnants of a Foreign Life in China" which served as the introduction of the book. We incorporated an address that Tenney delivered to Dartmouth students in 1907: "Educational reform in China". We added a chronology and a bibliography of Tenney that Julie Wang compiled. We also included an academic article by Professor Niu Guanjie. Our book was published in 2015.

\section{CONCLUSION}

Based upon my experience of the Tenney's papers project, I offer the following in closing:

1. Develop projects aligned with libraries'strategic planning. As librarianship embraces rapid transformation and development with new modes of teaching, researching and publishing, it is central to librarians to stay adaptive and focused to adjust to ebb and flow. By following this principle, one can obtain a library administration's support, which is the first step towards any successful projects. When I became the East Asian librarian nine years ago, my primary responsibility was still largely based on physical collection, although it was already shifting towards licensed electronic resources. We then evolved into the era of internet when vast amount of information became easily available with everything connected by network. As digital humanities gradually gained momentum, we have embarked on projects of digitization, open access publishing and cross border collaborations while advancing into computerized data manipulation.

2. Collaboration, collaboration and collaboration. As many East Asian librarians in American academic institutions are solo librarians responsible for Chinese, Japanese and Korean collections, it is imperative to keep the team work spirit alive. In Tenney's papers project, for content, I had the moral and intellectual support from our faculty on campus and librarian colleagues from other institutions; For technological support, a steady work flow 
between preservation, cataloging, digital production team and Rauner Special Collections Library enabled a smooth advancement from stage to stage; for the publication, the book would not have come out in time to be used for Crossley's history class had it not been to the diligent, excellent proof reading and editing skills demonstrated by our editor at Guangxi Normal University Press.

3. Dare to enter uncharted waters. The expansion of digital technology in academic libraries lead to exploration of innovative ideas and new design possibilities unknown before. By actively engaging in these explorations, librarians can stretch their imagination, develop their potentials and create collections of originality that combines ideas with technology. Since the completion of the Tenney's project, I have undertaken a new collection on the "Up to the Mountains and down to the Countryside Movement" in the 60s and 70s. So far, I have collected over 1,500 pages of diaries, manuscripts, photos and artifacts for the library. At the same time, we have also conducted over twenty hours of oral history video recordings. I envision that the library will produce a multifaceted online resource that incorporates an image collection, an interactive searchable text collection, and an oral history video collection, all presented on a single platform. Although Dartmouth College Library hasn't yet experimented with a production of this nature, the initial scanning and metadata of the materials have been completed and related departments have shown an increased curiosity and interest in working on this ongoing project towards our goal.

Moving forward, opportunities for digital humanities are abundant with positions of digital humanities librarians and digital humanities centers created at many institutions accompanied by new tools and technologies. Librarians will continue to play a key role in the future development. We will work collaboratively to increase our specialized digital collections, promote scholarly online publication, create projects of web archiving on topics of common interest, engage in text mining and analytics to assist scholars, and we will further explore for the best model of digital humanities.

\section{References}

Crossley, P. K. Personal correspondence, December 18, 2013.

Dartmouth College Library Guide to the Papers of Charles D. Tenney, circa 1919 - 1986. Retrieved April 23, 2018, from http://ead.dartmouth.edu/html/ms794_fullguide.html

\section{About the author}

Nien Lin Xie is the Librarian for East Asian Studies at Dartmouth College Library. 